\title{
Physiology, Growth and Yield of Different Cassava Genotypes Planted in Upland with Dry Environment during High Storage Root Accumulation Stage
}

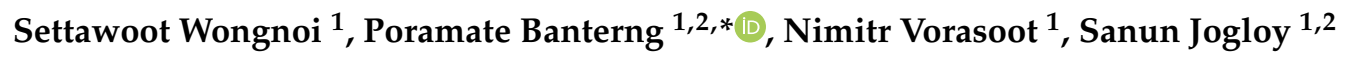 \\ and Piyada Theerakulpisut ${ }^{3}$ \\ 1 Department of Agronomy, Faculty of Agriculture, Khon Kaen University, Khon Kaen 40002, Thailand; \\ settawoot_w@hotmail.com (S.W.); nimitr1945@gmail.com (N.V.); sjogloy@gmail.com (S.J.) \\ 2 Plant Breeding Research Center for Sustainable Agriculture, Faculty of Agriculture, Khon Kaen University, \\ Khon Kaen 40002, Thailand \\ 3 Department of Biology, Faculty of Science, Khon Kaen University, Khon Kaen 40002, Thailand; \\ piythe@kku.ac.th \\ * Correspondence: bporam@kku.ac.th; Tel.: +66-43-342-949; Fax: +66-43-364-636
}

Received: 17 March 2020; Accepted: 13 April 2020; Published: 17 April 2020

\begin{abstract}
Additional information on the physiological performances for different cassava genotypes would support better decision-making about desirable genetic resources for water-limited conditions. The objective of this study was to evaluate the physiological expression and yield of eight different cassava genotypes grown under a dry environment during high storage root accumulation. The eight cassava genotypes, i.e., Kasetsart 50, Huay Bong 80, Rayong 5, Rayong 7, Rayong 9, Rayong 11, Rayong 90, and CMR38-125-77 were evaluated under rain-fed upland conditions at Khon Kaen University, Thailand, during 2018 to 2020. A randomized complete block design (RCBD) with three replications was used. Soil moisture contents, chlorophyll fluorescence ( $\mathrm{Fv} / \mathrm{Fm}$ and $\left.\mathrm{Fv}^{\prime} / \mathrm{Fm}^{\prime}\right)$, net photosynthesis (Pn), stomatal conductance, water use efficiency (WUE), relative water content (RWC) for leaf, leaf area index (LAI), specific leaf area (SLA), starch content, crop dry weight, and starch yield were observed at 180, 270, and 360 days after planting (DAP), and weather data during the experimental period were also recorded. The results from both 2018/2019 and 2019/2020 indicated that Pn was positively and significantly correlated with stomatal conductance and Fv/Fm during the high storage root accumulation stage (270 and $360 \mathrm{DAP})$ with soil moisture content lower than field capacity. CMR38-125-77 had satisfactory performances in Pn, RWC, $\mathrm{Fv} / \mathrm{Fm}, \mathrm{Fv}^{\prime} / \mathrm{Fm}^{\prime}$, stomatal conductance, LAI, SLA, WUE, biomass, starch content, and starch yield at a last growth stage with soil moisture content lower than permanent wilting point. Significant association between crop dry weight and WUE at 360 DAP was recorded, and CMR38-125-77 and Kasetsart 50 were classified as favorable genotypes with high WUE and biomass.
\end{abstract}

Keywords: chlorophyll fluorescence; dry weight; photosynthesis; starch content; water stress; water use efficiency

\section{Introduction}

Cassava is an important economic crop in the world, and it is widely cultivated in tropical and subtropical regions [1,2]. There are many uses of cassava, such as for food, animal feed, alcohol, biofuel, detergents, textiles, plastic, and other pharmaceutical products [3-6]. Due to the world population increasing, therefore, the global demand for cassava is also scaling up.

Thailand is recognized as a major cassava producer, yielding approximately 31.2 million tons in 2017 [7]. The average productivity in a country is approximately 23 ton ha ${ }^{-1}$, which is a lower than 
expected yield ( 80 ton $\mathrm{ha}^{-1}$ ) [2]. Most of the farmers in Thailand have cultivated the cassava under rainfed conditions in upland areas with the occurrence of water shortages during the growing period, leading to water stress and low productivity [8,9]. Breeding and selection for high yield potential and for smaller yield reduction when a crop is affected by the limited water is an alternative strategy to overcome such a problem in a sustainable manner.

In the past, selection of cassava genotypes in Thailand were mostly done based on the criteria of storage root yield, harvest index, and starch content at final harvest [10]. Additional information based on other physiological traits can help to shed light on the behavior and adaptability of each cassava genotype. These physiological characteristics also support the efficiency of selecting the appropriate cassava genotypes for the farmers, as well as for further breeding programs. De Tafur et al. [11] found a positive relationship between net photosynthesis (Pn) and storage root dry weight of cassava grown under rainfed conditions at the northern coast of Colombia, with a dry period occurring six months after planting. Oyetunji et al. [12] reported the performances on chlorophyll fluorescence and biomass of two cassava genotypes (TMS 4(2) 1425 and TME1) grown under water stress for 3-6 months at the International Institute of Tropical Agriculture (IITA), Ibadan, Nigeria. The data in terms of relative water content (RWC), chlorophyll fluorescence, and biomass for cassava genotypes were documented for growing in a greenhouse with water stress during the early growth stage [13] and for planting under rainfed conditions (water shortages between 2 to 6 months after planting) in upper paddy fields during the off-season of rice [14]. However, there is no evidence of physiological characteristics with respect to $\mathrm{Pn}$, crop water status, chlorophyll fluorescence $\left(\mathrm{Fv} / \mathrm{Fm}\right.$ and $\left.\mathrm{Fv}^{\prime} / \mathrm{Fm}^{\prime}\right)$, stomatal conductance, and water use efficiency (WUE) coupled with biomass and yield of other commercial cassava genotypes grown under rainfed upland conditions with limited water during a growth period, of high partitioning to storage root (9-12 months after planting) [15] in Thailand.

Therefore, it is necessary to explore the physiological characteristics and yield associated with dry conditions during high accumulation of storage root for cassava grown under rainfed conditions. This information will support the decision-making to select a recommended cultivar and a suitable parent to breed for terminal drought conditions. The good parental sources can help to enhance the success of new released genotypes. The objective of this study was to evaluate the performances on physiology and yield of eight different cassava genotypes grown under a dry environment during high storage root formation.

\section{Materials and Methods}

The seven commercial cassava genotypes (Kasetsart 50, Huay Bong 80, Rayong 5, Rayong 7, Rayong 9, Rayong 11, and Rayong 90) and an elite line (CMR38-125-77) were evaluated under rainfed upland conditions at the Faculty of Agriculture, University of Khon Kaen, Thailand, from March 2018 to March 2019 (2018/2019) and during March 2019 to March 2020 (2019/2020, Figure 1). The soil type for the experimental field was Yasothon series (Oxic Paleustult), which is sandy loam that represents the recommended soil texture for cassava in Thailand. 


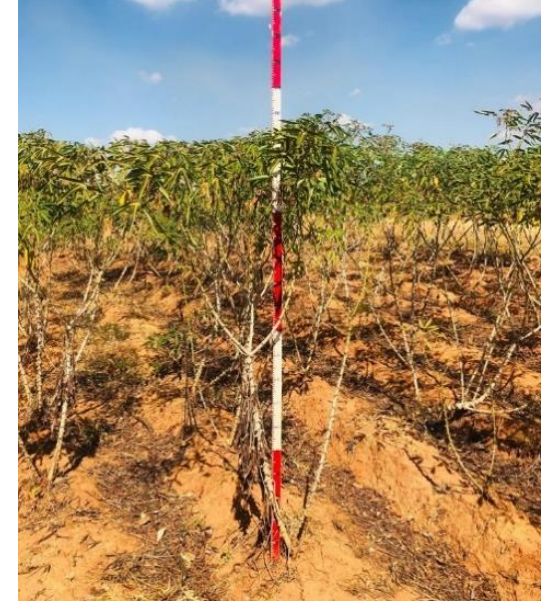

(A) Rayong 5

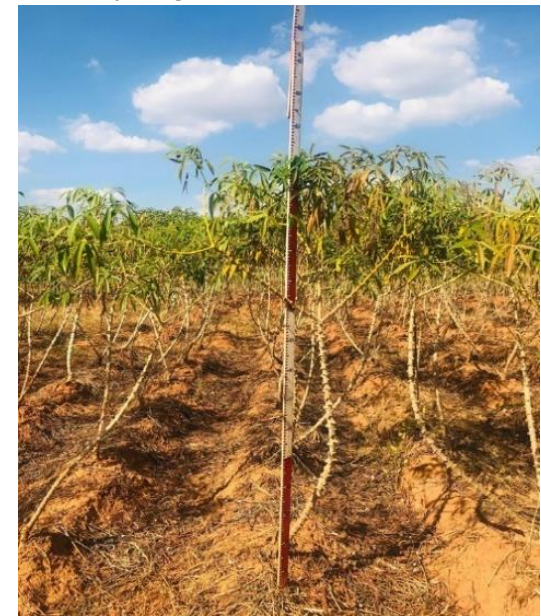

(E) Rayong 90

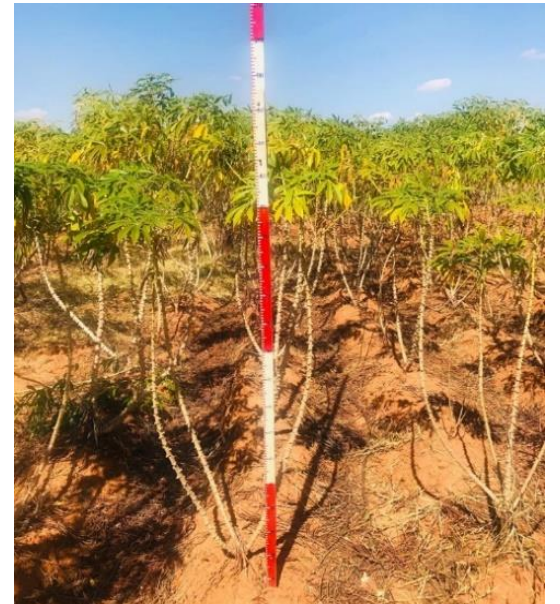

(B) Rayong 7

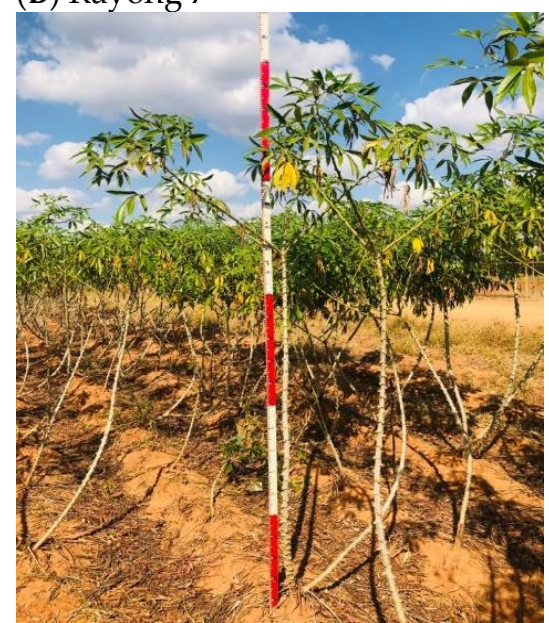

(F) Kasetsart 50

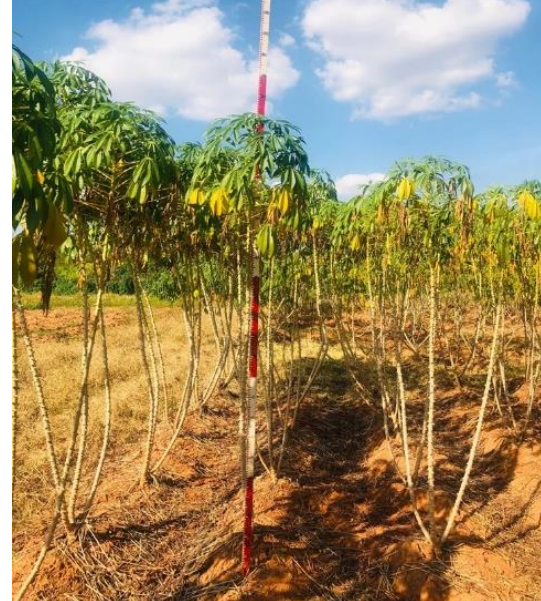

(C) Rayong 9

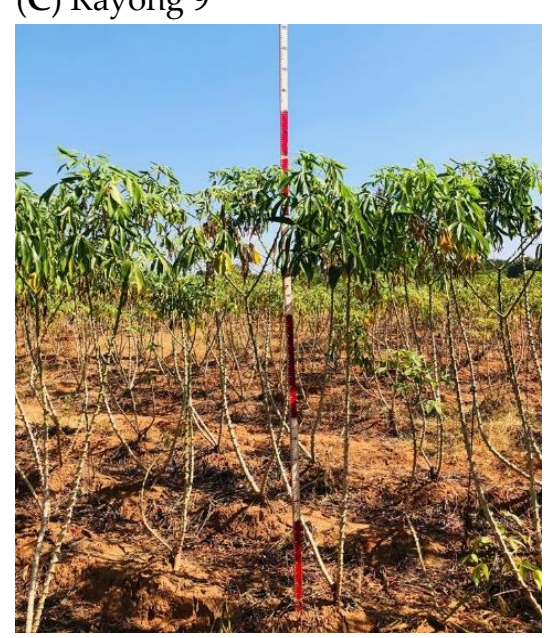

(G) Huay Bong 80

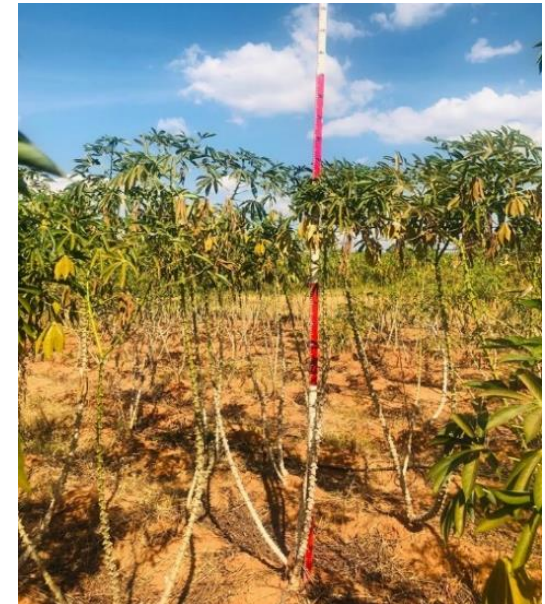

(D) Rayong 11

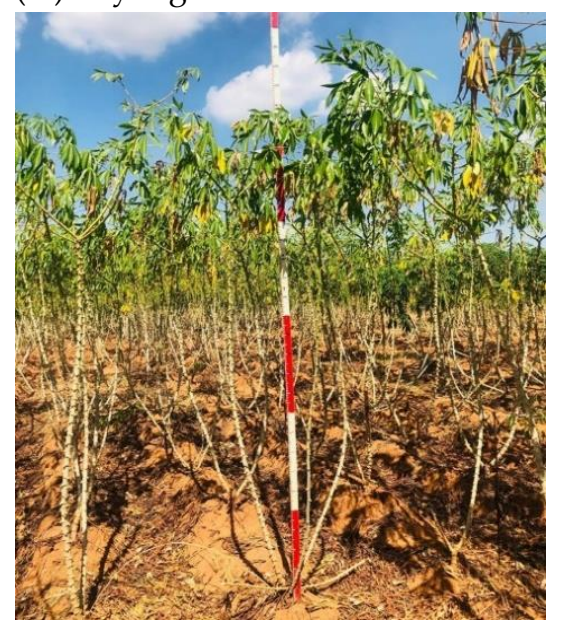

(H) CMR38-125-77

Figure 1. The eight different cassava genotypes (A-H) at 10 months after planting (dry period) for an experiment during 2019/2020 in Khon Kaen University, Thailand. There was limited rainfall from 8 up to 12 months after planting. 
For each experimental year, a randomized complete block design (RCBD) with three replications was assigned. Individual plot size was $102 \mathrm{~m}^{2}$ with a spacing between plots of $1 \mathrm{~m}$. Land preparation was conducted by following the normal procedures for cassava experiments and the soil ridges were created. The stems of cassava at 12 months after planting were cut as sticks to $20 \mathrm{~cm}$ in length and soaked with thiamethoxam $25 \%$ at a water rate of $4 \mathrm{~g}$ per $20 \mathrm{~L}$ of water, for $5-10 \mathrm{~min}$ to get rid of aphid flour attached to the pieces. The sticks of the eight cassava genotypes were inserted in the soil ridge (2/3 of the length was buried) at March 2018 and were planted again at March 2019, which represent the planting date in early rainy season in Thailand. A spacing of $1 \mathrm{~m}$ between rows and $1 \mathrm{~m}$ between plants within the row was assigned. There was a total of 306 sticks for each treatment. Irrigation was done during the first month after planting in order to facilitate the uniformity of plant population, and the crop was then allowed to grow under rainfed condition up to final harvest. Manual weed control was conducted to avoid the competition. A chemical fertilizer (Chiataicompanylimited, Phranakhonsiayutthaya, Thailand) 15-7-18 $\left(\mathrm{N}^{-} \mathrm{P}_{2} \mathrm{O}_{5}-\mathrm{K}_{2} \mathrm{O}\right)$ was applied at a rate of $312.5 \mathrm{~kg} \mathrm{ha}^{-1}$ at 30 and 60 days after planting (DAP).

For the association between climatic factors, soil water status and crop performances (Figure 2), those data were observed in the time of crop duration. Soil moisture contents were monitored at the growth stages of maximum growth rate of the leaf (180 DAP), high carbohydrate partitioning to storage root (270 DAP), and high storage root dry matter (360 DAP) [15] by collecting two random soil samples for each replication at the depths of $0-15,15-30$ and $30-45 \mathrm{~cm}$. The initial weights of the soil samples were recorded. The samples were then dried in the oven at $105^{\circ} \mathrm{C}$ until reaching the constant weight, and the dry weights of soil were observed. The calculation of soil moisture content was based on the gravimetric method described by Shukla et al. (2014) [16] as below (1). The field capacity and permanent wilting point were estimated using a pressure plate instrument.

$$
\text { Soil moisture content }=\frac{\text { Weight of wet soil }- \text { Weight of dry soil }}{\text { Weight of dry soil }} \times 100(\%)
$$

Net photosynthesis, stomatal conductance, and WUE (2) [17] were recorded at 180, 270, and 360 DAP from the young matured leaves (5th position from the top) of two plants in each experimental plot by using Li-cor6400xt (Li-Cor, Inc., Lincoln, NE, USA) with PAR at $1500 \mu \mathrm{mol} \mathrm{m}^{-2} \mathrm{~s}^{-1}$ and $\mathrm{CO}_{2}$ concentration at $400 \mu \mathrm{mol} \mathrm{mol}{ }^{-1}$.

$$
\text { WUE }=\frac{\text { Photosynthesis }}{\text { Transpiration }}\left(\mu \mathrm{molCO}_{2} \mathrm{~mm}^{-1} \mathrm{H}_{2} \mathrm{O}\right)
$$

On the same day, then, measurements of chlorophyll fluorescence were done for the same leaves as Pn observation, using Mini Pam II (Heinz Walz GmbH, Effeltrich, Germany) under natural light conditions (starting from 9.00-10.00 a.m.) to measure maximum efficiency of photosystem II photochemistry in the light $\left(\mathrm{Fv}^{\prime} / \mathrm{Fm}^{\prime}\right)$. The same leaves were then preadapted to a dark period for one hour by fixing special tags on each leaf blade before measurements were retaken. After one hour of dark adaptation, the sensor cup was fitted on the leaf for measurement of maximum quantum efficiency of photosystem II photochemistry (Fv/Fm) [12,14,18-21]. Relative water content (RWC) for those the same leaves as Pn and chlorophyll fluorescence evaluations were recorded between 9.00-10.00 a.m., where $1 \mathrm{~cm}^{2}$ in leaf area was collected using a leaf disc borer. Leaves were kept in plastic tubes in an ice box and transported to the laboratory, and leaf fresh weight was recorded. The leaf samples were then soaked in distilled water for $24 \mathrm{~h}$ at room temperature (approximately $25^{\circ} \mathrm{C}$ ) under dim light conditions and blotted for surface drying, and the saturated weight of the leaf was then measured. The samples were oven-dried at $80^{\circ} \mathrm{C}$ for at least $72 \mathrm{~h}$ or until the leaf weights were constant, and the leaf dry weight was recorded. The values of RWC for the leaf were also calculated based on the sampled 
leaf fresh weight (FW), dry weight of sampled leaf (DW), and the saturated weight of sampled leaf (SW) [14,22], as the formula below (3):

$$
\mathrm{RWC}=\frac{\mathrm{FW}-\mathrm{DW}}{\mathrm{SW}-\mathrm{DW}} \times 100(\%) .
$$

Crop dry weight, LAI, SLA, and starch content for each experimental plot were observed from six sampled plants at 180 and $270 \mathrm{DAP}$, and from twelve sampled plants at final harvest (360 DAP). The plants were harvested and separated into leaves, storage root, and the remaining part. All plant organs were then subsampled (approximately $10 \%$ of total fresh weight of each organ). Subsamples of green leaf were used to measure leaf area using a leaf area meter (LI-Cor 3100, LI-COR Inc., Lincoln, NE, USA). The subsamples of all plant organs were oven dried at $80^{\circ} \mathrm{C}$ until a constant weight to determine the dry weight of the individual plant organ. The LAI values were calculated as the ratio of canopy leaf area to ground area, and the values for SLA were recorded as the ratio of leaf area per leaf dry weight. Starch contents of storage roots were determined by using the specific gravity method [23], and starch yields were calculated as a function of starch contents and weights of storage root. In addition, daily maximum temperature, minimum temperature, amount of solar radiation, and rainfall during the growing periods were recorded by a weather station (WatchDog 2000; Spectrum Technologies, Inc., Lincoln, NE, USA).

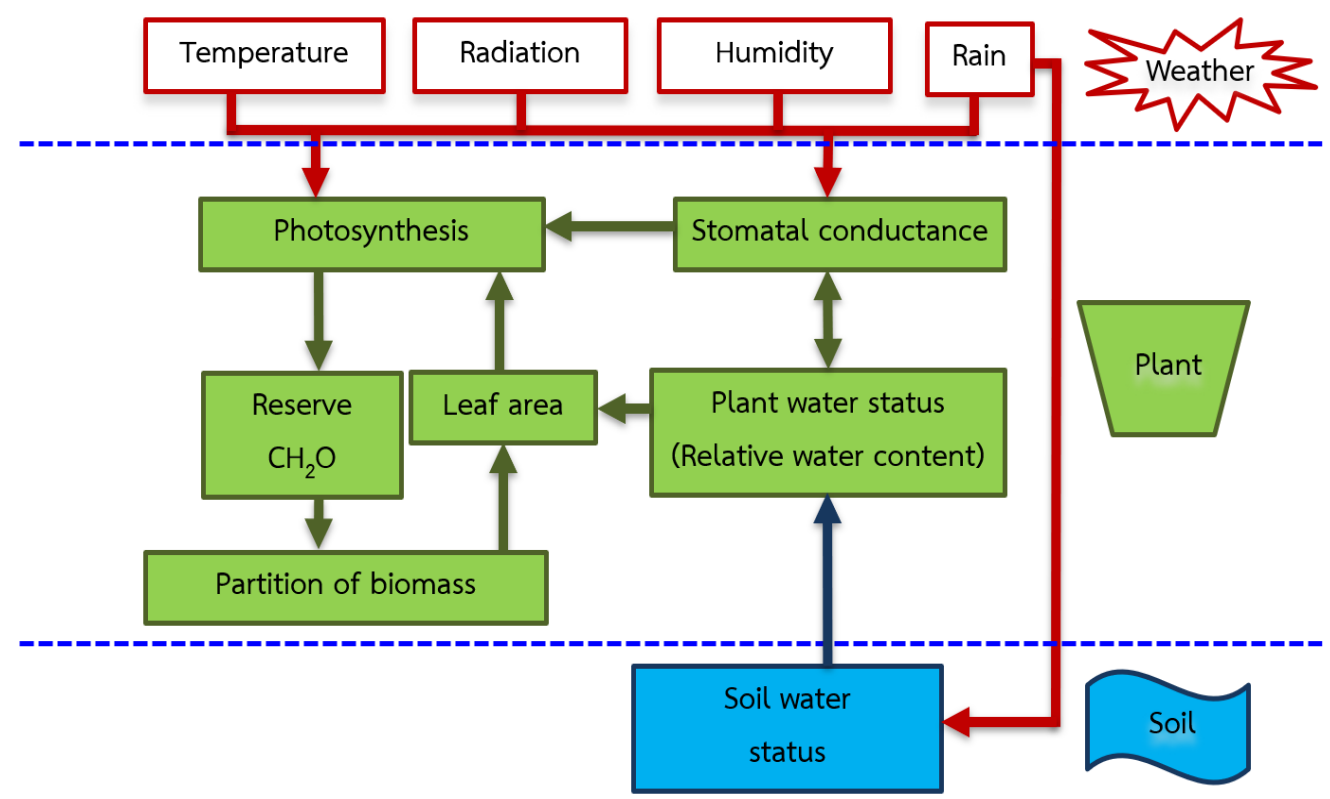

Figure 2. Conceptual framework concerning climatic factors, soil moisture content and cassava physiology.

Analysis of variance (ANOVA) was performed for all crop traits by following the model of RCBD. Mean comparison based on the least significant difference test (LSD) was done. Correlation coefficients (r) were calculated to determine the association among Pn and other physiological traits for 180, 270 and 360 DAP (at different growth stages), and to explain the linear relationship between biomass and WUE for a growth stage under water-limited at 360 DAP (late growing stage). All the statistical analyses were done by following the procedure of Gomez and Gomez [24] and by using the Statistix 10 program [25]. 


\section{Results and Discussion}

\subsection{Weather and Soil Water Conditions}

For both experimental years, the period of the wet season was observed from 70 to 270 DAP (Figure 3) and then followed by the occurrence of the dry period up to the final harvest (360 DAP). This caused variation in soil water status throughout the crop duration. The recorded values of soil moisture contents at 270 and $360 \mathrm{DAP}$ were lower than the field capacity $(\mathrm{FC})$ and closer to the permanent wilting point (PWP), respectively. The observed values for the total amount of rainfall during the growing periods were $1131 \mathrm{~mm}$ and $957.51 \mathrm{~mm}$ for 2018/2019 and 2019/2020, respectively. During the period of 270 to $360 \mathrm{DAP}$, in addition, there were slightly higher relative humidity and solar radiation, with a little lower minimum temperature than during the early growing period. Based on our field inspection during the dry period, no water table in an experimental area was also recorded (data not shown).

\subsection{Performances of Cassava Genotypes}

The results for all three different crop ages (180, 270, and 360 DAP) form an experiment in 2018/2019 (Table 1) indicated that CMR38-125-77 and Kasetsart 50 produced a high total dry weight $(p<0.01)$, and CMR38-125-77 was a superior genotype for storage root dry weight $(p<0.01)$. For 2019/2020, CMR38-125-77 gave a high total dry weight $(p<0.05, p<0.01)$ and storage root dry weight $(p<0.01)$ for all three different crop ages. Kasetsart 50 is also one of interesting genotypes as it had high storage root dry weights at 360 DAP for both 2018/2019 and 2019/2020 $(p<0.01)$. The preferable performance of a CMR38-125-77 genotype based on biomass and yield in Thailand was recorded for planting under well water management [26], and under rainfed upper paddy field conditions during off-season of rice [14,27]. In addition to CMR38-125-77, the genotypes Rayong 7 and Rayong 9 also showed better performances of storage root and total dry weights at $180 \mathrm{DAP}$ (at rainfall season) than at 270 and 360 DAP (during late rainy season and dry season) for both 2018/2019 and 2019/2020 (Table 1 and Figure 3), indicating a good response of these genotypes to well water conditions, and they would be recommended as the genetic resources for planting under irrigated condition.

According to the information for starch production in 2018/2109 (Table 2), the CMR38-125-77 genotype had high starch contents $(p<0.05$ and $p<0.01)$, and starch yields $(p<0.01)$ for all three crop ages. Kasetsart 50 performed well in terms of starch yield $(p<0.01)$ for all observations. The results for all three crop ages from an experiment in 2019/2020 indicated that Rayong 11 and Huay Bong 80 gave greater values of starch $(p<0.01)$, while CMR38-125-77 produced higher starch yield $(p<0.01)$. Greater values of starch yields for Kasetsart 50 and CMR38-125-77 at 360 DAP for both 2018/2019 and $2019 / 2020$ as compared to the others $(p<0.01)$ were due to high storage root dry weight of these two genotypes (Table 1). High starch yields at 6 months after planting for the genotypes CMR38-125-77 and Kasetsart 50 were also observed for planting under rainfed upper paddy field conditions during off-season of rice in Thailand [14], and this clearly indicates the potential of these two genotypes as genetic materials to improve starch yield. High values of starch content at 180 DAP for CMR38-125-77 and Huay Bong 80 genotypes $(p<0.01)$ for both experimental years (Table 2$)$ indicate that they are early starch production genotypes and suitable as a resource for short crop duration. Rayong 9 is also a genotype with respect to high starch content at 270 and 360 DAP for both 2018/2019 and 2019/2020.

A CMR38-125-77 gave higher LAI values for all three crop ages in 2018/2019 $(p<0.01)$ and for 270 and 360 DAP in 2019/2020 ( $p<0.01$ (Table 3). Lower values of LAI were observed at 270 and 360 DAP when compared to the values at $180 \mathrm{DAP}$, and the shortage of rainfall during late rainy season up to dry season would be a reason of this occurrence (Figure 3). Leaves are an important source for cassava growth, and the number of leaves in the canopy could be reduced by drought effect [1]. Leaf area index was used to distinguish the response of cassava to water stress, and the appropriate value of LAI would be a beneficial source for canopy photosynthesis as well as crop yield [1,28-30]. The optimal values for LAI of cassava grown at the International Center for Tropical Agriculture (CIAT) in Colombia have been reported and it ranges from 3 to 3.5, and cassava crop should maintain this LAI level as 
long as possible to achieve high storage root yield [28]. For the results of SLA in 2018/2019, there was no significant difference among genotypes for SLA at all three observations (Table 3). According to 2019/2020, however, there were significant differences for SLA among genotypes $(p<0.01)$ and CMR38-125-77 showed higher values for all three different crop ages. Comparing among the three different crop ages, smaller SLA values were recorded at the period of lower rainfall (Table 3 and Figure 3). A report from El-Sharkawy et al. [31] indicated that the thickness of the leaf as described by SLA is increased by water stress.

Smaller values of RWC for leaf at 270 and 360 DAP as compared to at 180 DAP were observed in both 2018/2019 and 2019/2020 (Table 4), and this is the effect of lower rainfall and soil moisture content (Figure 3). The droughting of cassava leads to a reduction in leaf RWC [13]. The plants with high ability to maintain RWC in leaf during the drought period are identified as drought tolerant genotypes. Our data reviewed that there was significant difference among genotypes $(p<0.01)$ for RWC at 360 DAP both 2018/2019 and 2019/2020, and Rayong 9 and Rayong 11 had the lowest values (Table 4). For stomatal conductance, the values at 270 and 360 DAP were lower than at 180 DAP for both 2018/2019 and 2019/2020. Leaves of plants grown under a nonwater stress environment tend to have higher values of stomatal conductance than leaves in stress $[9,32]$. The lower stomatal conductance is an expression of reduced water loss through partial stomatal closure. Rapid closing of stomata in response to diminished soil moisture content has been documented as a mechanism of drought tolerance genotypes $[1,33]$. Considering the performance between the tested cassava genotypes for the growth stages with soil moisture contents lower than field capacity (270 DAP) in both 2018/2019 and 2019/2020, Rayong 7, Rayong 9, and CMR38-125-77 showed higher values of stomatal conductance $(p<0.01)$. For a growth stage with soil moisture contents lower than permanent wilting point (360 DAP), the highest stomatal conductance values were observed for Rayong 7, Rayong 90, and CMR38-125-77 in 2018/2019 $(p<0.01)$ and for CMR38-125-77 in 2019/2020 ( $p<0.01)$.

The values of $\mathrm{Fv}^{\prime} / \mathrm{Fm}^{\prime}$ and $\mathrm{Fv} / \mathrm{Fm}$ at different crop ages in both 2018/2019 and 2019/2020 were shown in Table 5. The lower values were found at 270 and 360 DAP or in less soil moisture content (Figure 3). The data from 2018/2019 reviewed that Kasetsart 50 and Huay Bong 80 had the lowest $\mathrm{Fv}^{\prime} / \mathrm{Fm}^{\prime}$ value at $360 \mathrm{DAP}(p<0.01)$, while Huay Bong 80 and Rayong 5 had the lowest value for $\mathrm{Fv} / \mathrm{Fm}$ at 270 DAP $(p<0.05)$. In 2019/2020, low values of $\mathrm{Fv}^{\prime} / \mathrm{Fm}^{\prime}$ were observed for Rayong 5, Rayong 11, Rayong 7, and Huay Bong 80 at 360 DAP ( $p<0.01$ ), while Rayong 5, Rayong 11, Kasetsart 50, Huay Bong 80, and Rayong 90 were classified as a group of low Fv/Fm value at 270 DAP $(p<0.01)$. Observation based on chlorophyll fluorescence is an alternative strategy to help classify the superior cassava genotypes. High values of $\mathrm{Fv}^{\prime} / \mathrm{Fm}^{\prime}$ and $\mathrm{Fv} / \mathrm{Fm}$ indicate high quantum efficiency of photochemistry and heat dissipation that produce more photosynthate. The genotypes with low value of $\mathrm{Fv}^{\prime} / \mathrm{Fm}^{\prime}$ and $\mathrm{Fv} / \mathrm{Fm}$ during water shortage period might be identified as drought susceptible genotypes [14].

The results for both 2018/2019 and 2019/2020 (Table 6) clearly demonstrated that Pn values at 180 DAP were higher than at the other two crop ages for all genotypes. This might be the result of a good distribution of rainfall that could help maintains soil moisture (Figure 3), which supports crop photosynthesis activity. Investigation on the performance of different cassava genotypes by using high-throughput screening of Pn could provide valuable information for breeding to improve cassava yield under various environments [34,35]. According to the comparisons of the Pn values during water-limited condition at 270 and 360 DAP among different genotypes for 2018/2019 (Table 6), Rayong 7 and CMR38-125-77 had higher performance in photosynthesis when compared to the other genotypes $(p<0.01)$. For 2019/2020, a CMR38-125-77 genotype showed higher Pn performance for both 270 and 360 DAP $(p<0.01)$. Based on WUE in 2018/2019, CMR38-125-77, Kasetsart 50, Rayoug 9, and Rayong 11 showed higher values of WUE at the dry period of 360 DAP $(p<0.01)$. The results of WUE for 2019/2020 demonstrated that CMR38-125-77 had high WUE for both at 270 and 360 DAP. These genotypes would be profitable genetic resources to improve cassava yield for dry periods during the late growth stage. High water use efficiency is a result of crop drought tolerance mechanism, and it is also a desirable trait for screening of cassava genotypes grown under water shortage situations $[1,36]$. 

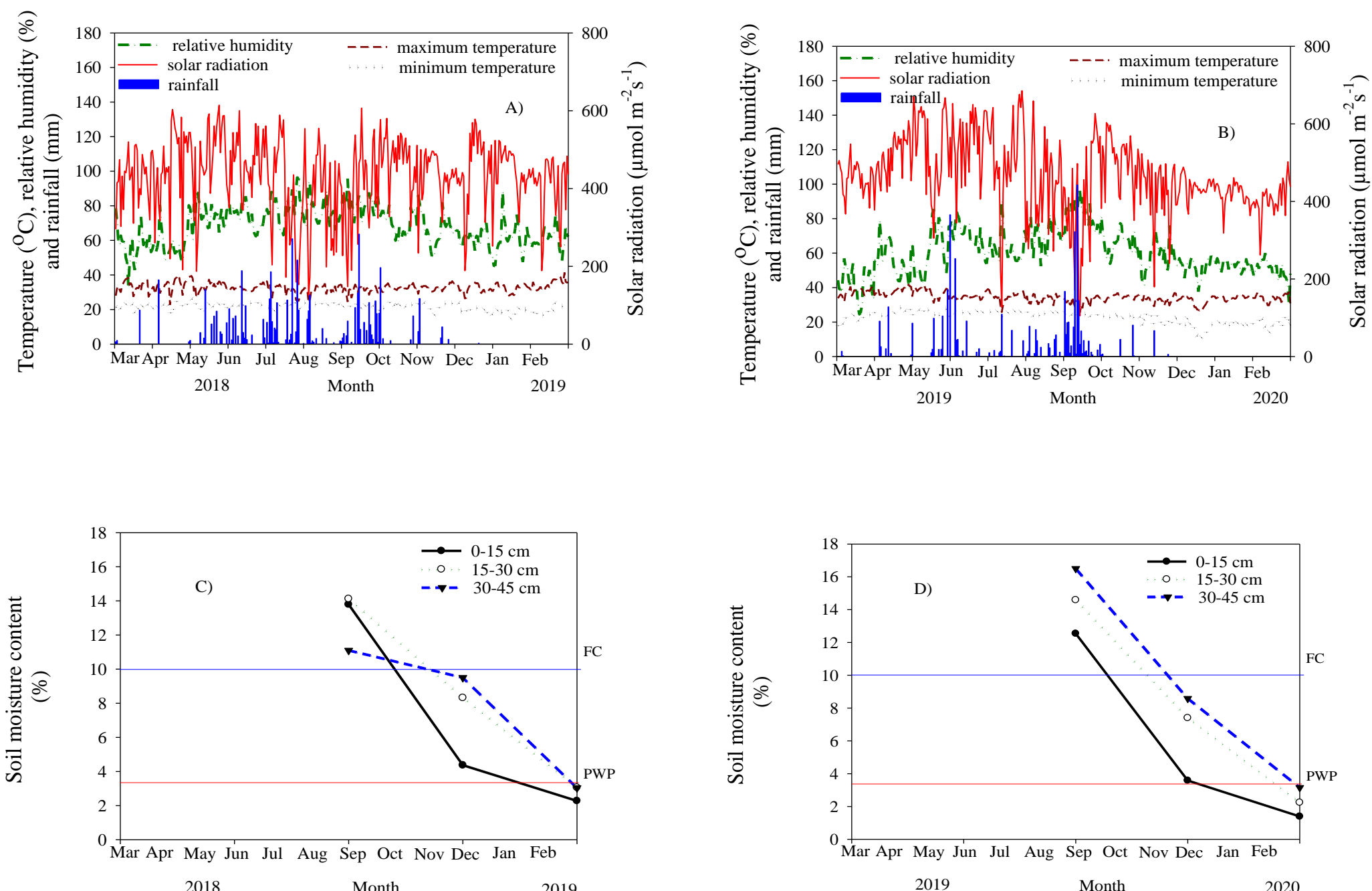

Figure 3. Weather conditions for 2018/2019 (A) and 2019/2020 (B) at Khon Kaen University, Thailand. Soil moisture contents at three different soil depths for 2018/2019 (C) and 2019/2020 (D) (FC = field capacity and PWP = permanent wilting point). 
Table 1. Total and storage root dry weights at different days after planting (DAP) for eight cassava genotypes grown in 2018/2019 and 2019/2020.

\begin{tabular}{|c|c|c|c|c|c|c|c|c|c|c|c|c|}
\hline \multirow{3}{*}{ Genotype } & \multicolumn{6}{|c|}{$2018 / 2019$} & \multicolumn{6}{|c|}{$2019 / 2020$} \\
\hline & \multicolumn{3}{|c|}{ Total Dry Weight (ton ha-1) } & \multicolumn{3}{|c|}{ Storage Root Dry Weight (ton ha ${ }^{-1}$ ) } & \multicolumn{3}{|c|}{ Total Dry Weight (ton ha-1) } & \multicolumn{3}{|c|}{ Storage Root Dry Weight (ton ha ${ }^{-1}$ ) } \\
\hline & 180 DAP & 270 DAP & 360 DAP & 180 DAP & 270 DAP & 360 DAP & 180 DAP & 270 DAP & 360 DAP & 180 DAP & 270 DAP & 360 DAP \\
\hline Rayong 5 & $12.4 \mathrm{bc}$ & $22.9 \mathrm{bcd}$ & $20.3 \mathrm{bc}$ & $6.7 \mathrm{~d}$ & $10.5 \mathrm{~cd}$ & $12.4 \mathrm{c}$ & $14.9 \mathrm{bc}$ & $22.9 \mathrm{bcd}$ & $24.9 \mathrm{bcd}$ & $9.5 \mathrm{~cd}$ & 14.2 de & 18.5 cde \\
\hline Rayong 7 & $15.9 \mathrm{ab}$ & $24.3 \mathrm{bcd}$ & $19.0 \mathrm{~b}$ & $11.5 \mathrm{ab}$ & $11.8 \mathrm{bcd}$ & $14.3 \mathrm{bc}$ & $16.9 \mathrm{a}$ & 21.2 cde & $25.7 \mathrm{~b}$ & $12.6 \mathrm{a}$ & $15.9 \mathrm{c}$ & $19.5 \mathrm{~cd}$ \\
\hline Rayong 9 & $15.7 \mathrm{ab}$ & $20.9 \mathrm{~cd}$ & $22.6 \mathrm{~b}$ & $10.6 \mathrm{ab}$ & $10.1 \mathrm{~d}$ & $17.0 \mathrm{~b}$ & $16.5 \mathrm{a}$ & $21.0 \mathrm{de}$ & $26.0 \mathrm{~b}$ & $13.4 \mathrm{a}$ & $14.6 \mathrm{~d}$ & $19.8 \mathrm{~cd}$ \\
\hline Rayong 11 & $10.0 \mathrm{c}$ & $19.3 \mathrm{~d}$ & $20.1 \mathrm{~b}$ & $5.5 \mathrm{~d}$ & $10.0 \mathrm{~d}$ & $14.4 \mathrm{bc}$ & $12.6 \mathrm{~d}$ & $21.0 \mathrm{de}$ & $22.3 \mathrm{~d}$ & $8.5 \mathrm{~d}$ & $14.1 \mathrm{de}$ & $16.5 \mathrm{e}$ \\
\hline Rayong 90 & $12.4 \mathrm{bc}$ & $19.5 \mathrm{~d}$ & $19.2 \mathrm{~b}$ & $8.0 \mathrm{c}$ & $10.2 \mathrm{~d}$ & $14.2 \mathrm{bc}$ & $14.7 \mathrm{bc}$ & $20.3 \mathrm{e}$ & $23.1 \mathrm{~cd}$ & $10.0 \mathrm{c}$ & $13.4 \mathrm{e}$ & $17.8 \mathrm{de}$ \\
\hline Kasetsart 50 & $16.4 \mathrm{a}$ & $26.0 \mathrm{abc}$ & $30.2 \mathrm{a}$ & $10.3 \mathrm{~b}$ & $12.3 \mathrm{bc}$ & $21.3 \mathrm{a}$ & $15.9 \mathrm{ab}$ & $23.8 \mathrm{~b}$ & $30.7 \mathrm{a}$ & $11.3 \mathrm{~b}$ & $19 a$ & $24.3 \mathrm{a}$ \\
\hline Huay Bong 80 & $11.1 \mathrm{c}$ & $26.6 \mathrm{ab}$ & $21.8 \mathrm{~b}$ & $6.6 \mathrm{~d}$ & $12.9 \mathrm{~b}$ & $16.8 \mathrm{~b}$ & $14.2 \mathrm{c}$ & $23.1 \mathrm{~b}$ & $26.3 b$ & $12.6 \mathrm{a}$ & $17.1 \mathrm{~b}$ & $21.1 b c$ \\
\hline CMR38-125-77 & $17.0 \mathrm{a}$ & $29.5 \mathrm{a}$ & $30.9 \mathrm{a}$ & $11.7 \mathrm{a}$ & $15.6 \mathrm{a}$ & $22.2 \mathrm{a}$ & $16.7 \mathrm{a}$ & $27.4 \mathrm{a}$ & $30.4 \mathrm{a}$ & $13.3 \mathrm{a}$ & $18.8 \mathrm{a}$ & $23.3 \mathrm{ab}$ \\
\hline F-test & ** & ** & $* *$ & ** & $* *$ & ** & * & $* *$ & $* *$ & ** & ** & $* *$ \\
\hline C.V. & 14.75 & 12.76 & 11.43 & 8.17 & 9.48 & 10.94 & 4.65 & 5.20 & 5.79 & 5.01 & 3.66 & 7.70 \\
\hline
\end{tabular}

C.V. $=$ coefficient of variation, NS, ${ }^{*}$ and ${ }^{* *}=$ nonsignificant, statistical significance at $p<0.05$, and statistical significance at $p<0.01$, respectively. Values in column followed by the same letter are not significantly different by Duncan's multiple range test. The sizes of sample for 180 and 270 DAP and for 360 DAP were 6 and $12 \mathrm{~m}^{2}$, respectively.

Table 2. Starch content and starch yield at different days after planting (DAP) for eight cassava genotypes grown in 2018/2019 and 2019/2020.

\begin{tabular}{|c|c|c|c|c|c|c|c|c|c|c|c|c|}
\hline \multirow{3}{*}{ Genotype } & \multicolumn{6}{|c|}{$2018 / 2019$} & \multicolumn{6}{|c|}{$2019 / 2020$} \\
\hline & \multicolumn{3}{|c|}{ Starch Content (\%) } & \multicolumn{3}{|c|}{ Starch Yield (ton ha ${ }^{-1}$ ) } & \multicolumn{3}{|c|}{ Starch Content (\%) } & \multicolumn{3}{|c|}{ Starch Yield (ton ha ${ }^{-1}$ ) } \\
\hline & 180 DAP & 270 DAP & 360 DAP & 180 DAP & 270 DAP & 360 DAP & 180 DAP & 270 DAP & 360 DAP & 180 DAP & 270 DAP & 360 DAP \\
\hline Rayong 5 & $23.4 \mathrm{e}$ & $27.3 \mathrm{c}$ & $23.1 \mathrm{e}$ & $3.4 \mathrm{c}$ & $6.5 \mathrm{~d}$ & $6.8 \mathrm{c}$ & $22.6 \mathrm{e}$ & $30 c$ & $27.5 \mathrm{~b}$ & $5.7 \mathrm{~d}$ & $11.9 \mathrm{~b}$ & $12.6 \mathrm{de}$ \\
\hline Rayong 7 & $26.6 \mathrm{bc}$ & $30.5 \mathrm{ab}$ & $29.3 \mathrm{bc}$ & $5.3 \mathrm{a}$ & $8.4 \mathrm{bcd}$ & $9.9 \mathrm{~b}$ & $25.4 \mathrm{bcd}$ & $33.4 \mathrm{a}$ & $28.3 \mathrm{~b}$ & $8.1 \mathrm{~b}$ & $11.4 \mathrm{bc}$ & 13.6 cde \\
\hline Rayong 9 & 24.3 de & $30.6 \mathrm{ab}$ & $30.0 \mathrm{ab}$ & $4.4 \mathrm{~b}$ & $7.0 \mathrm{~cd}$ & $10.4 \mathrm{~b}$ & $24.3 \mathrm{~cd}$ & $33.5 \mathrm{a}$ & $31.9 \mathrm{a}$ & $8.3 \mathrm{ab}$ & $8.5 \mathrm{e}$ & $14.7 \mathrm{bd}$ \\
\hline Rayong 11 & 25.2 cde & $30.9 \mathrm{ab}$ & $28.5 \mathrm{bcd}$ & $2.6 \mathrm{~d}$ & $7.0 \mathrm{~cd}$ & $8.5 \mathrm{bc}$ & $25.9 \mathrm{abc}$ & $33.1 \mathrm{ab}$ & $31.2 \mathrm{a}$ & $5.7 \mathrm{~d}$ & $10.5 \mathrm{~d}$ & $12.1 \mathrm{e}$ \\
\hline Rayong 90 & $26.6 \mathrm{bc}$ & $29.3 \mathrm{bc}$ & $27.4 \mathrm{~cd}$ & $4.6 \mathrm{~b}$ & $6.7 \mathrm{~cd}$ & $8.4 \mathrm{bc}$ & $25.0 \mathrm{bcd}$ & $33.3 \mathrm{ab}$ & $30.5 \mathrm{a}$ & $6.4 \mathrm{c}$ & $10.7 \mathrm{~cd}$ & $12.6 \mathrm{de}$ \\
\hline Kasetsart 50 & $25.7 \mathrm{~cd}$ & $32.6 \mathrm{a}$ & $26.4 \mathrm{~d}$ & $5.4 \mathrm{a}$ & $9.7 \mathrm{ab}$ & $14.2 \mathrm{a}$ & 23.9 de & $32.4 \mathrm{~b}$ & $30.3 \mathrm{a}$ & $7.9 \mathrm{~b}$ & $13.7 \mathrm{a}$ & $18.3 \mathrm{a}$ \\
\hline Huay Bong 80 & $28.3 \mathrm{ab}$ & $32.9 \mathrm{a}$ & $26.4 \mathrm{~d}$ & $3.3 \mathrm{c}$ & $9.0 \mathrm{bc}$ & $10.4 \mathrm{~b}$ & $27.4 \mathrm{a}$ & $33.6 \mathrm{a}$ & $30.3 \mathrm{a}$ & $8.3 \mathrm{ab}$ & $13.3 \mathrm{a}$ & $15.3 \mathrm{bc}$ \\
\hline CMR38-125-77 & $29.3 \mathrm{a}$ & $31.7 \mathrm{ab}$ & $32 \mathrm{a}$ & $5.9 \mathrm{a}$ & $11.6 \mathrm{a}$ & $16.2 \mathrm{a}$ & $26.2 \mathrm{ab}$ & $32.3 \mathrm{~b}$ & $30.4 \mathrm{a}$ & $8.9 \mathrm{a}$ & $13.9 \mathrm{a}$ & $16.6 \mathrm{ab}$ \\
\hline F-test & ** & * & ** & ** & ** & $* *$ & ** & ** & $* *$ & ** & ** & ** \\
\hline C.V. & 4.65 & 5.64 & 4.91 & 8.0 & 17.53 & 11.58 & 3.66 & 1.7 & 3.58 & 5.56 & 3.87 & 9.74 \\
\hline
\end{tabular}

C.V. $=$ coefficient of variation, $\mathrm{NS}^{*}$ and ${ }^{* *}=$ non-significant, statistical significance at $p<0.05$, and statistical significance at $p<0.01$, respectively. Values in column followed by the same letter are not significantly different by Duncan's multiple range test. The sizes of sample for 180 and 270 DAP and for 360 DAP were 6 and $12 \mathrm{~m}^{2}$ per plot, respectively. 
Table 3. Leaf area index (LAI) and specific leaf area (SLA) at different days after planting (DAP) for eight cassava genotypes grown in 2018/2019 and 2019/2020.

\begin{tabular}{|c|c|c|c|c|c|c|c|c|c|c|c|c|}
\hline \multirow{3}{*}{ Genotype } & \multicolumn{6}{|c|}{$2018 / 2019$} & \multicolumn{6}{|c|}{$2019 / 2020$} \\
\hline & \multicolumn{3}{|c|}{ LAI } & \multicolumn{3}{|c|}{ SLA $\left(\mathrm{cm}^{2} \mathrm{~g}^{-1}\right)$} & \multicolumn{3}{|c|}{ LAI } & \multicolumn{3}{|c|}{ SLA $\left(\mathrm{cm}^{2} \mathrm{~g}^{-1}\right)$} \\
\hline & 180 DAP & 270 DAP & 360 DAP & 180 DAP & 270 DAP & 360 DAP & 180 DAP & 270 DAP & 360 DAP & 180 DAP & 270 DAP & 360 DAP \\
\hline Rayong 5 & $2.38 \mathrm{bc}$ & $0.93 c$ & $0.16 \mathrm{~d}$ & 183 & 175 & 84 & $2.9 \mathrm{c}$ & $1.04 \mathrm{c}$ & $0.19 \mathrm{~d}$ & $185 \mathrm{abc}$ & 165 cde & $81 \mathrm{ab}$ \\
\hline Rayong 7 & $2.53 \mathrm{ab}$ & $0.92 c$ & $0.17 \mathrm{~cd}$ & 187 & 171 & 86 & $2.7 \mathrm{~cd}$ & $1.03 \mathrm{c}$ & $0.20 \mathrm{~cd}$ & $198 \mathrm{a}$ & 162 de & $84 \mathrm{a}$ \\
\hline Rayong 9 & $2.61 \mathrm{ab}$ & $1.02 \mathrm{c}$ & $0.17 \mathrm{~cd}$ & 185 & 175 & 87 & $2.3 \mathrm{e}$ & $1.09 \mathrm{c}$ & $0.20 \mathrm{~cd}$ & $182 \mathrm{bc}$ & $167 \mathrm{bcd}$ & $83 a$ \\
\hline Rayong 11 & $2.18 \mathrm{~cd}$ & $1.15 \mathrm{~b}$ & $0.18 \mathrm{bc}$ & 187 & 170 & 89 & $1.9 \mathrm{f}$ & $1.26 \mathrm{~b}$ & $0.21 \mathrm{c}$ & $159 \mathrm{~d}$ & $161 \mathrm{~d}$ & $77 \mathrm{~b}$ \\
\hline Rayong 90 & $2.02 \mathrm{~d}$ & $1.16 \mathrm{~b}$ & $0.18 \mathrm{bc}$ & 185 & 174 & 87 & $2.9 \mathrm{c}$ & $1.26 \mathrm{~b}$ & $0.20 \mathrm{~cd}$ & $193 a b$ & $163 \mathrm{de}$ & $83 \mathrm{a}$ \\
\hline Kasetsart 50 & $2.74 \mathrm{a}$ & $1.20 \mathrm{~b}$ & $0.20 \mathrm{ab}$ & 193 & 176 & 90 & $3.8 \mathrm{a}$ & $1.32 \mathrm{~b}$ & $0.23 \mathrm{~b}$ & $187 \mathrm{abc}$ & $171 \mathrm{bc}$ & $83 \mathrm{a}$ \\
\hline Huay Bong 80 & $2.30 \mathrm{bcd}$ & $1.25 \mathrm{~b}$ & $0.18 \mathrm{bc}$ & 187 & 174 & 89 & $2.5 \mathrm{de}$ & $1.41 \mathrm{a}$ & $0.20 \mathrm{~cd}$ & $176 \mathrm{c}$ & $172 \mathrm{~b}$ & $84 \mathrm{a}$ \\
\hline CMR38-125-77 & $2.61 \mathrm{ab}$ & $1.39 \mathrm{a}$ & $0.21 \mathrm{a}$ & 191 & 184 & 88 & $3.3 \mathrm{~b}$ & $1.48 \mathrm{a}$ & $0.26 \mathrm{a}$ & $186 \mathrm{abc}$ & $180 \mathrm{a}$ & 84 a \\
\hline F-test & $* *$ & $* *$ & $* *$ & NS & NS & NS & $* *$ & $* *$ & $* *$ & $* *$ & $* *$ & $* *$ \\
\hline C.V. & 7.30 & 5.68 & 6.70 & 2.28 & 4.59 & 4.64 & 7.10 & 3.24 & 5.20 & 4.37 & 2.13 & 2.65 \\
\hline
\end{tabular}

C.V. $=$ coefficient of variation, NS and ${ }^{* *}=$ nonsignificant and statistical significance at $p<0.01$, respectively. Values in column followed by the same letter are not significantly different by Duncan's multiple range test. The sizes of sample for 180 and 270 DAP and for 360 DAP were 6 and $12 \mathrm{~m}^{2}$ per plot, respectively.

Table 4. Relative water content for leaf (RWC) and stomatal conductance at different days after planting (DAP) for eight cassava genotypes grown in 2018/2019 and $2019 / 2020$

\begin{tabular}{|c|c|c|c|c|c|c|c|c|c|c|c|c|}
\hline \multirow{3}{*}{ Genotype } & \multicolumn{6}{|c|}{$2018 / 2019$} & \multicolumn{6}{|c|}{$2019 / 2020$} \\
\hline & \multicolumn{3}{|c|}{ RWC (\%) } & \multicolumn{3}{|c|}{$\begin{array}{l}\text { Stomatal Conductance } \\
\qquad\left(\mathrm{molH}_{2} \mathrm{O} \mathrm{m}^{-2} \mathrm{~s}^{-1}\right)\end{array}$} & \multicolumn{3}{|c|}{ RWC (\%) } & \multicolumn{3}{|c|}{$\begin{array}{l}\text { Stomatal Conductance } \\
\quad\left(\mathrm{molH}_{2} \mathrm{O} \mathrm{m}^{-2} \mathrm{~s}^{-1}\right)\end{array}$} \\
\hline & 180 DAP & 270 DAP & 360 DAP & 180 DAP & 270 DAP & 360 DAP & 180 DAP & 270 DAP & 360 DAP & 180 DAP & 270 DAP & 360 DAP \\
\hline Rayong 5 & 90.1 & 83.9 & $76.9 a$ & $0.44 \mathrm{~d}$ & $0.15 \mathrm{~d}$ & $0.13 \mathrm{~d}$ & 91.4 & $82.4 \mathrm{~b}$ & $77.5 \mathrm{ab}$ & 0.45 & $0.15 \mathrm{e}$ & $0.14 \mathrm{e}$ \\
\hline Rayong 7 & 87.1 & 82.9 & $76 \mathrm{ab}$ & $0.45 \mathrm{~d}$ & $0.33 a$ & $0.30 \mathrm{a}$ & 92.6 & $82.1 \mathrm{~b}$ & $76.2 \mathrm{bc}$ & 0.42 & $0.33 \mathrm{a}$ & $0.25 \mathrm{~b}$ \\
\hline Rayong 9 & 86.9 & 86.5 & $71.4 \mathrm{c}$ & $0.64 \mathrm{a}$ & $0.32 \mathrm{a}$ & $0.14 \mathrm{~cd}$ & 90.8 & $81.8 \mathrm{~b}$ & $73.1 \mathrm{~d}$ & 0.50 & $0.35 \mathrm{a}$ & $0.19 \mathrm{~d}$ \\
\hline Rayong 11 & 89.0 & 81.7 & $73.2 \mathrm{bc}$ & $0.44 \mathrm{~d}$ & $0.26 \mathrm{~b}$ & $0.17 \mathrm{bc}$ & 93.8 & $84.9 \mathrm{a}$ & $74.6 \mathrm{~cd}$ & 0.46 & $0.22 \mathrm{c}$ & $0.14 \mathrm{e}$ \\
\hline Rayong 90 & 92.1 & 83.8 & $77.6 \mathrm{a}$ & $0.52 \mathrm{~b}$ & $0.26 \mathrm{~b}$ & $0.30 \mathrm{a}$ & 90.9 & $81.9 \mathrm{~b}$ & $77.5 \mathrm{ab}$ & 0.51 & $0.25 \mathrm{~b}$ & $0.21 \mathrm{c}$ \\
\hline Kasetsart 50 & 91.6 & 84.5 & $77.3 \mathrm{a}$ & $0.55 \mathrm{~b}$ & $0.21 \mathrm{c}$ & $0.14 \mathrm{~cd}$ & 94.7 & $85.2 \mathrm{a}$ & $77.7 \mathrm{ab}$ & 0.45 & $0.26 \mathrm{~b}$ & $0.24 \mathrm{~b}$ \\
\hline Huay Bong 80 & 91.5 & 84.1 & $73.7 \mathrm{~b}$ & $0.47 \mathrm{~cd}$ & $0.14 \mathrm{~d}$ & $0.18 \mathrm{~b}$ & 92.8 & $83.3 \mathrm{ab}$ & $75.2 \mathrm{~cd}$ & 0.48 & $0.19 \mathrm{~d}$ & $0.17 \mathrm{~d}$ \\
\hline CMR38-125-77 & 90.1 & 87.2 & $78.9 \mathrm{a}$ & $0.55 \mathrm{~b}$ & $0.31 \mathrm{a}$ & $0.28 \mathrm{a}$ & 92.6 & $83.6 \mathrm{ab}$ & $78.8 \mathrm{a}$ & 0.50 & $0.33 \mathrm{a}$ & $0.29 \mathrm{a}$ \\
\hline F-test & NS & NS & ** & $* *$ & ** & $* *$ & NS & * & ** & NS & ** & ** \\
\hline C.V. & 2.98 & 2.55 & 2.28 & 6.05 & 7.55 & 10.70 & 1.97 & 1.45 & 1.51 & 6.44 & 5.95 & 6.01 \\
\hline
\end{tabular}

C.V. = coefficient of variation, NS, ${ }^{*}$ and ${ }^{* *}=$ nonsignificant, statistical significance at $p<0.05$, and statistical significance at $p<0.01$, respectively. Values in column followed by the same letter are not significantly different by Duncan's multiple range test. The size of sample was $2 \mathrm{~m}^{2}$ (2 plants per plot). 
Table 5. Effective quantum yield of PSII photochemistry $\left(\mathrm{Fv}^{\prime} / \mathrm{Fm}^{\prime}\right)$ and maximum photochemical quantum yield of PSII (Fv/Fm) at different days after planting (DAP) for eight cassava genotypes grown in 2018/2019 and 2019/2020.

\begin{tabular}{|c|c|c|c|c|c|c|c|c|c|c|c|c|}
\hline \multirow{3}{*}{ Genotype } & \multicolumn{6}{|c|}{$2018 / 2019$} & \multicolumn{6}{|c|}{$2019 / 2020$} \\
\hline & \multicolumn{3}{|c|}{$\mathbf{F v}^{\prime} / \mathbf{F m}^{\prime}$} & \multicolumn{3}{|c|}{ Fv/Fm } & \multicolumn{3}{|c|}{$\mathbf{F v}^{\prime} / \mathbf{F m}^{\prime}$} & \multicolumn{3}{|c|}{$\mathrm{Fv} / \mathrm{Fm}$} \\
\hline & 180 DAP & 270 DAP & 360 DAP & 180 DAP & 270 DAP & 360 DAP & 180 DAP & 270 DAP & 360 DAP & 180 DAP & 270 DAP & 360 DAP \\
\hline Rayong 5 & 0.59 & 0.41 & $0.36 \mathrm{ab}$ & 0.81 & $0.63 c$ & 0.58 & 0.50 & 0.46 & $0.33 \mathrm{e}$ & 0.80 & $0.67 c$ & 0.61 \\
\hline Rayong 7 & 0.53 & 0.45 & $0.38 \mathrm{ab}$ & 0.85 & $0.71 \mathrm{ab}$ & 0.65 & 0.53 & 0.48 & 0.35 cde & 0.80 & $0.70 \mathrm{ab}$ & 0.63 \\
\hline Rayong 9 & 0.58 & 0.47 & $0.41 \mathrm{a}$ & 0.80 & $0.72 \mathrm{a}$ & 0.63 & 0.55 & 0.50 & $0.37 \mathrm{bc}$ & 0.83 & $0.71 \mathrm{a}$ & 0.63 \\
\hline Rayong 11 & 0.56 & 0.41 & $0.37 \mathrm{ab}$ & 0.81 & $0.71 \mathrm{ab}$ & 0.63 & 0.52 & 0.50 & $0.34 \mathrm{de}$ & 0.81 & $0.67 c$ & 0.63 \\
\hline Rayong 90 & 0.52 & 0.43 & $0.40 \mathrm{a}$ & 0.85 & $0.69 \mathrm{ab}$ & 0.69 & 0.57 & 0.46 & $0.36 \mathrm{bcd}$ & 0.84 & $0.69 \mathrm{abc}$ & 0.60 \\
\hline Kasetsart 50 & 0.59 & 0.40 & $0.34 \mathrm{~b}$ & 0.82 & $0.67 \mathrm{abc}$ & 0.63 & 0.56 & 0.44 & $0.38 \mathrm{ab}$ & 0.82 & $0.68 \mathrm{bc}$ & 0.65 \\
\hline Huay Bong 80 & 0.56 & 0.42 & $0.33 \mathrm{~b}$ & 0.83 & $0.66 \mathrm{bc}$ & 0.63 & 0.57 & 0.48 & 0.35 cde & 0.82 & $0.68 \mathrm{bc}$ & 0.62 \\
\hline CMR38-125-77 & 0.61 & 0.47 & $0.41 \mathrm{a}$ & 0.85 & $0.73 \mathrm{a}$ & 0.68 & 0.57 & 0.47 & $0.39 \mathrm{a}$ & 0.82 & $0.72 \mathrm{a}$ & 0.67 \\
\hline F-test & NS & NS & $* *$ & NS & $*$ & NS & NS & NS & $* *$ & NS & $* *$ & NS \\
\hline C.V. & 7.03 & 8.76 & 7.77 & 7.87 & 4.63 & 6.55 & 5.90 & 9.44 & 3.85 & 3.24 & 2.44 & 3.18 \\
\hline
\end{tabular}

C.V. $=$ coefficient of variation, NS, ${ }^{*}$ and ${ }^{* *}=$ non-significant, statistical significance at $p<0.05$, and statistical significance at $p<0.01$, respectively. Values in column followed by the same

letter are not significantly different by Duncan's multiple range test. The size of sample was $2 \mathrm{~m}^{2}$ ( 2 plants per plot)

Table 6. Net photo synthesis (Pn) and water use efficiency (WUE) at different days after planting (DAP) for eight cassava genotypes grown in 2018/2019 and 2019/2020.

\begin{tabular}{|c|c|c|c|c|c|c|c|c|c|c|c|c|}
\hline \multirow{3}{*}{ Genotype } & \multicolumn{6}{|c|}{ 2018/2019 } & \multicolumn{6}{|c|}{$2019 / 2020$} \\
\hline & \multicolumn{3}{|c|}{$\operatorname{Pn}\left(\mu \mathrm{mol} \mathrm{CO} \mathrm{Cm}^{-2} \mathrm{~s}^{-1}\right)$} & \multicolumn{3}{|c|}{ WUE $\left(\mu \mathrm{molCO}_{2} \mathrm{~mm}^{-1} \mathrm{H}_{2} \mathrm{O}\right)$} & \multicolumn{3}{|c|}{$\operatorname{Pn}\left(\mu \mathrm{mol} \mathrm{CO} \mathrm{Cm}^{-2} \mathrm{~s}^{-1}\right)$} & \multicolumn{3}{|c|}{ WUE $\left(\mu \mathrm{molCO}_{2} \mathrm{~mm}^{-1} \mathrm{H}_{2} \mathrm{O}\right)$} \\
\hline & 180 DAP & 270 DAP & 360 DAP & 180 DAP & 270 DAP & 360 DAP & 180 DAP & 270 DAP & 360 DAP & 180 DAP & 270 DAP & 360 DAP \\
\hline Rayong 5 & $27.4 \mathrm{ab}$ & $15.6 \mathrm{~cd}$ & $14.9 \mathrm{~cd}$ & 5.8 & 5.6 & $5.7 \mathrm{bc}$ & 27.1 & $15.9 \mathrm{e}$ & $15.1 \mathrm{e}$ & 5.4 & $5.7 \mathrm{bc}$ & $6.1 \mathrm{~b}$ \\
\hline Rayong 7 & $26.3 \mathrm{bcd}$ & $24.0 \mathrm{a}$ & $19.5 \mathrm{a}$ & 5.4 & 5.3 & $5.2 \mathrm{c}$ & 26.5 & $20.0 \mathrm{bc}$ & $18.8 \mathrm{~b}$ & 5.3 & $5.5 \mathrm{~cd}$ & $6.0 \mathrm{~b}$ \\
\hline Rayong 9 & $28.4 \mathrm{a}$ & $23.2 \mathrm{a}$ & $14.5 \mathrm{~cd}$ & 5.2 & 5.0 & $6.3 \mathrm{ab}$ & 27.2 & $21.0 \mathrm{ab}$ & $17.8 \mathrm{~cd}$ & 5.6 & $5.7 \mathrm{bc}$ & $6.0 \mathrm{~b}$ \\
\hline Rayong 11 & $25.5 \mathrm{~cd}$ & $17.5 \mathrm{bcd}$ & $16.3 \mathrm{bc}$ & 5.4 & 5.5 & $6.3 \mathrm{ab}$ & 26.4 & $17.1 \mathrm{de}$ & $17.6 \mathrm{~d}$ & 5.7 & $5.9 \mathrm{~b}$ & $6.1 \mathrm{~b}$ \\
\hline Rayong 90 & $25.4 \mathrm{~cd}$ & 18.9 bc & $18.8 \mathrm{a}$ & 4.7 & 5.1 & $5.1 \mathrm{c}$ & 27.3 & $18.6 \mathrm{~cd}$ & 18.4 bc & 5.3 & $5.3 \mathrm{~d}$ & $5.8 \mathrm{c}$ \\
\hline Kasetsart 50 & $26.6 b c$ & $18.4 \mathrm{bcd}$ & $17.8 \mathrm{ab}$ & 5.3 & 5.6 & $6.8 \mathrm{a}$ & 27.0 & $18.7 \mathrm{~cd}$ & $18.0 \mathrm{~cd}$ & 5.6 & $5.7 \mathrm{bc}$ & $6.5 \mathrm{a}$ \\
\hline Huay Bong 80 & $25.0 \mathrm{~d}$ & $14.8 \mathrm{~d}$ & $13.0 \mathrm{~d}$ & 5.4 & 5.6 & $5.8 \mathrm{bc}$ & 27.0 & $17.3 \mathrm{de}$ & $15.1 \mathrm{e}$ & 5.5 & $6.0 \mathrm{~b}$ & $5.9 \mathrm{bc}$ \\
\hline CMR38-125-77 & $27.7 \mathrm{ab}$ & $21.1 \mathrm{ab}$ & $18.8 \mathrm{a}$ & 5.0 & 6.0 & $6.9 a$ & 26.1 & $22.4 \mathrm{a}$ & $22.3 \mathrm{a}$ & 5.9 & $6.4 \mathrm{a}$ & $6.6 \mathrm{a}$ \\
\hline F-test & $* *$ & $* *$ & $* *$ & NS & NS & ** & NS & $* *$ & $* *$ & NS & $* *$ & ** \\
\hline C.V. & 3.03 & 10.73 & 7.17 & 6.40 & 8.21 & 8.06 & 4.70 & 5.16 & 2.07 & 3.98 & 3.37 & 2.25 \\
\hline
\end{tabular}

$\mathrm{C} . \mathrm{V} .=$ coefficient of variation, NS and ${ }^{* *}=$ nonsignificant and statistical significance at $p<0.01$, respectively. Values in column followed by the same letter are not significantly different by

Duncan's multiple range test. The size of sample was $2 \mathrm{~m}^{2}$ ( 2 plants per plot). 


\subsection{Correlation between Pn and Other Physiological Traits for Different Soil Water Status}

Correlation analysis among Pn and other physiological traits are shown in Table 7. A degree of association with statistical significance $(p<0.05)$ was observed between Pn and stomatal conductance $(r=0.50)$ for $2018 / 2019$ at a growth stage with a high soil moisture content (180 DAP). At a growth stage with a soil moisture content lower than field capacity (270 DAP), the significant correlation coefficients $(p<0.01)$ were recorded for Pn and Fv/Fm ( $r=0.74$ and 0.75 for 2018/2019 and 2019/2020, respectively), as well as for Pn and stomatal conductance ( $r=0.85$ and 0.86 for 2018/2019 and 2019/2020, respectively). Under the lowest soil moisture content at late growing stage (360 DAP) for 2018/2019, Pn was significantly related to $\mathrm{Fv} / \mathrm{Fm}$, RWC for leaf, and stomatal conductance with the $\mathrm{r}$ values of $0.47(p<0.05), 0.52(p<0.01)$ and $0.73(p<0.01)$, respectively. For 2019/2020 at 360 DAP, the statistical significances for $\mathrm{r}$ values were also recorded between Pn and stomatal conductance $(0.81, p<0.01)$, $\mathrm{Fv} / \mathrm{Fm}(0.51, p<0.05)$ and $\mathrm{Fv}^{\prime} / \mathrm{Fm}^{\prime}(0.58, p<0.01)$.

As moderate to high levels of association between Pn and stomatal conductance and Fv/Fm at the two growth stages with soil moisture contents lower than field capacity for both 2018/2019 and 2019/2020, the degree of stomatal opening and the maximum photochemical quantum yield of photosystem II (PSII) were identified as physiological determinant of a net rate for $\mathrm{CO}_{2}$ assimilation for growing condition with low soil water status. The high value of stomatal conductance involves slow stomatal closure, leading to increased $\mathrm{CO}_{2}$ intake and a high Pn of cassava [37]. The high performance in $\mathrm{Fv} / \mathrm{Fm}$ indicates a large amount of quantum yield of photosystem II (PSII) and enhance crop photosynthesis [18]. This study pointed out the information for physiological traits such as Pn, stomatal conductance, and Fv/Fm that are easily measured, and would be useful to achieve a better understanding of physiological mechanism underlying the responses of different cassava genotypes for water-limited growing condition, and such this physiological information could contribute to the successful of cassava breeding for drought conditions. Based on the data for both 2018/2019 and 2019/2020, it clearly demonstrated that CMR38-125-77 had large values of Fv/Fm and stomatal conductance, which were related to high Pn for a growth stage with the lowest soil moisture content (lower than permanent wilting point) at 360 DAP (Tables 4-6). Also, CMR38-125-77 showed high performances in $\mathrm{Fv}^{\prime} / \mathrm{Fm}^{\prime}$ and RWC at 360 DAP for both 2018/2019 and 2019/2020 (Tables 4 and 5). There were, however, low correlation coefficients for Pn and Fv'/Fm' in 2018/2019 and for Pn and RWC in 2019/2020 (Table 7). Lawlor [38] and Lawlor and Cornic [39] used to report that the rate of leaf photosynthesis is decreased by decreasing of their RWC. For $\mathrm{Fv}^{\prime} / \mathrm{Fm}^{\prime}$, it represents effective quantum yield of PSII photochemistry, which is also one of the key factors for $\mathrm{CO}_{2}$ assimilation [18].

The correlations between Pn and the traits of WUE and crop dry weight were also calculated. Low levels of relationship were observed for almost all pairs for 2018/2019 (data not shown), except for the $r$ values at 180 DAP, which were statically significant results $(p<0.01)$ of 0.59 and 0.57 for Pn and dry matter of total biomass and storage root product, respectively. Rayong 9 and CMR38-125-77 are the preferable genotypes in terms of Pn and biomass values at 180 DAP. Low variation among tested genotypes for the performances in terms of Pn and WUE and biomass might be a cause for small degree of correlation. As described in previous reports, however, the leaf photosynthetic rates of cassava were positively correlated with storage root dry weight [9,34]. 
Table 7. Correlation coefficients (r) between net photosynthesis rate (Pn) and other physiological traits $(\mathrm{n}=24)$.

\begin{tabular}{|c|c|c|c|c|c|c|}
\hline \multirow{3}{*}{ Physiological Trait } & \multicolumn{6}{|c|}{ Pn } \\
\hline & \multicolumn{3}{|c|}{$2018 / 2019$} & \multicolumn{3}{|c|}{$2019 / 2020$} \\
\hline & 180 DAP & 270 DAP & 360 DAP & 180 DAP & 270 DAP & 360 DAP \\
\hline RWC at $180 \mathrm{DAP}$ & $-0.32 \mathrm{NS}$ & - & - & $-0.28 \mathrm{NS}$ & - & - \\
\hline RWC at $270 \mathrm{DAP}$ & - & $0.22 \mathrm{NS}$ & - & - & $-0.11 \mathrm{NS}$ & - \\
\hline RWC at $360 \mathrm{DAP}$ & - & - & $0.52 * *$ & - & - & $0.35 \mathrm{NS}$ \\
\hline Stomatal conductance at 180 DAP & 0.50 * & - & - & $0.23 \mathrm{NS}$ & - & - \\
\hline Stomatal conductance at $270 \mathrm{DAP}$ & - & $0.85^{* *}$ & - & - & $0.86^{* *}$ & - \\
\hline Stomatal conductance at 360 DAP & - & - & $0.73^{* *}$ & - & - & $0.81^{* *}$ \\
\hline $\mathrm{Fv} / \mathrm{Fm}$ at $180 \mathrm{DAP}$ & $-0.24 \mathrm{NS}$ & - & - & $0.17 \mathrm{NS}$ & - & - \\
\hline $\mathrm{Fv} / \mathrm{Fm}$ at $270 \mathrm{DAP}$ & - & $0.74^{* *}$ & - & - & $0.75^{* *}$ & - \\
\hline $\mathrm{Fv} / \mathrm{Fm}$ at $360 \mathrm{DAP}$ & - & - & $0.47^{*}$ & - & - & 0.51 * \\
\hline $\mathrm{Fv}^{\prime} / \mathrm{Fm}^{\prime}$ at $180 \mathrm{DAP}$ & $0.25 \mathrm{NS}$ & - & - & $0.10 \mathrm{NS}$ & - & - \\
\hline $\mathrm{Fv}^{\prime} / \mathrm{Fm}^{\prime}$ at $270 \mathrm{DAP}$ & - & $0.40 \mathrm{NS}$ & - & - & $0.19 \mathrm{NS}$ & - \\
\hline $\mathrm{Fv}^{\prime} / \mathrm{Fm}^{\prime}$ at $360 \mathrm{DAP}$ & - & - & $0.32 \mathrm{NS}$ & - & - & $0.58^{* *}$ \\
\hline
\end{tabular}

DAP = days after planting; RWC = relative water content for leaf; $\mathrm{Fv}^{\prime} / \mathrm{Fm}^{\prime}$ = effective quantum yield of PSII photochemistry; Fv/Fm = maximum photochemical quantum yield of PSII; NS, * and ${ }^{* *}=$ nonsignificant, statistical significance at $p<0.05$, and statistical significance at $p<0.01$, respectively.

\subsection{Relationship between Biomass and WUE for Dry Condition at 360 DAP}

Strong uphill linear relationships (Figure 4) were recorded between WUE and dry matter of total biomass $(\mathrm{r}=0.86(p<0.01)$ and $0.88(p<0.01)$ for 2018/2109 and 2019/2020, respectively) and storage root $(r=0.81(p<0.01)$ for both 2018/2109 and 2019/2020). The genotypes with high WUE and crop biomass are favorable for being cultivated under low soil water condition. CMR38-125-77 and Kasetsart 50 had the values of WUE and biomass higher than the average values at a late growth stage for both 2018/2109 and 2019/2020, and they would be satisfactory genetic resources for planting under water-limited condition during the late growing period. Huay Bong 80 had slightly higher storage root dry weight than the average for both experimental years, but it showed lower WUE. In 2018/2019, Rayong 11 had high value of WUE but it had lower values of dry matter for total biomass and storage root yield than the average values. Rayong 9 also had high WUE value, and it produced less total biomass than the average. However, a moderate value of storage root yield was observed for Rayong 9, and high partitioning to storage root for Rayong 9 could be a reason to support this result [40]. The cassava genotypes with high WUE from this study are preferable genetic resources for a breeding program to generate the drought resistant cultivar in the future. The relationships between WUE and dry matter at other growth stages (180 and $270 \mathrm{DAP})$ were also determined, but the results reviewed low levels of correlation (data not shown). This might be due to the effect of higher soil moisture contents at 180 and 270 DAP than at 360 DAP. Therefore, our study pointed out another interesting exploration that WUE is not only useful for better understanding about crop adaptation, but it can also be used to support the accuracy of genotypes identification for planting under water-limited condition during high storage root formation period. 

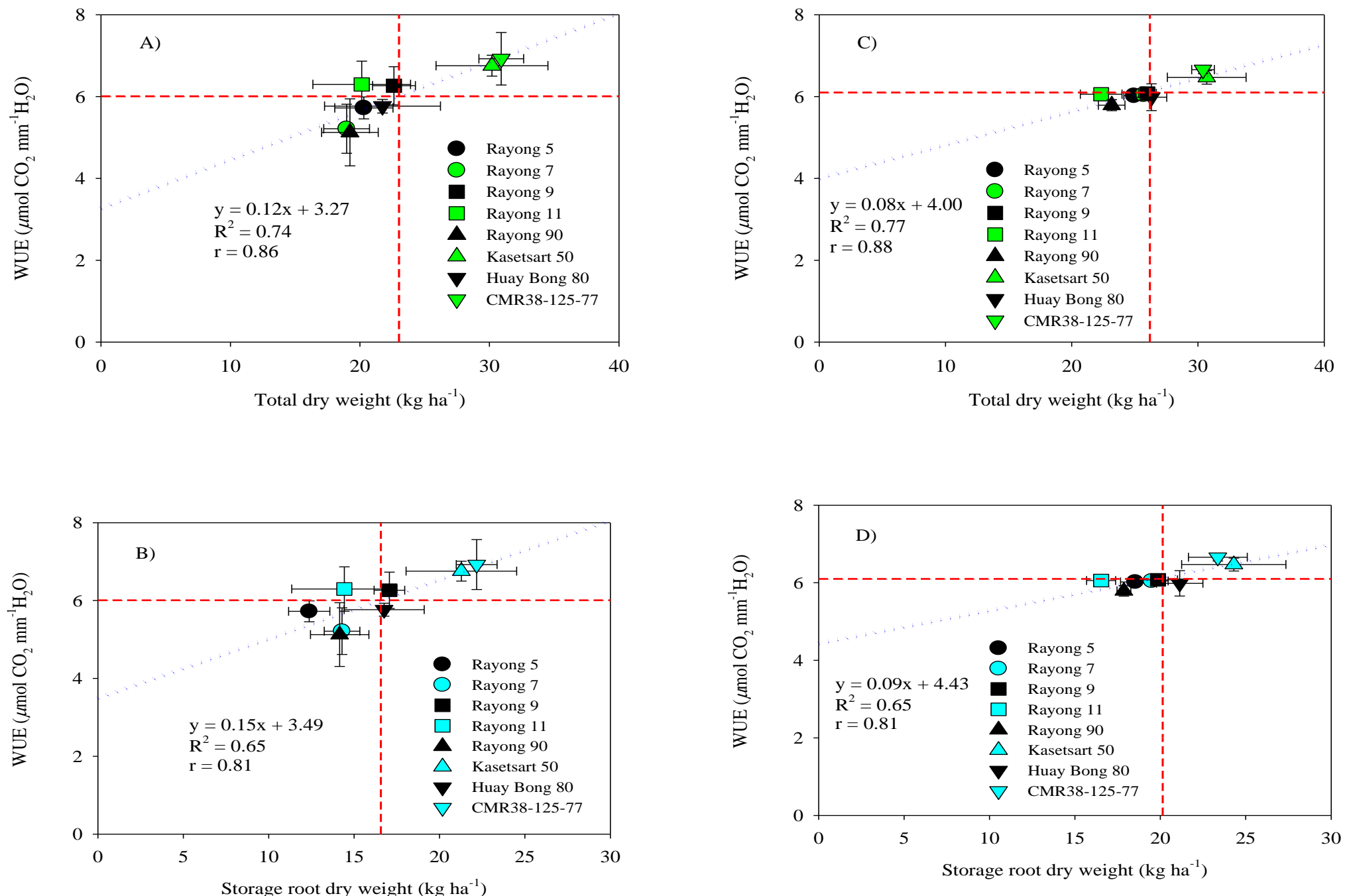

Figure 4. The relationship between biomass and water use efficiency (WUE) for eight different cassava genotypes at 2018/2019 (A,B) and at 2019/2020 (C,D). The dash lines represent means for biomass and WUE. 


\section{Conclusions}

This study reviewed the physiology, biomass and starch yield of eight different cassava genotypes planted under limited rainfall conditions during high storage root accumulation. The information from both 2018/2019 and 2019/2020 periods indicated that stomatal conductance and Fv/Fm are physiologically determinant of Pn at growing stages with soil moisture content lower than field capacity, indicating the potential of these physiological traits to support breeding for terminal drought tolerance. At a last growth stage with soil moisture content lower than permanent wilting point for both 2018/2019 and 2019/2020, high performances of a CMR38-125-77 genotype in biomass, starch content, and starch yield were due in part to superior values of $\mathrm{Pn}, \mathrm{RWC}, \mathrm{Fv} / \mathrm{Fm}, \mathrm{Fv}^{\prime} / \mathrm{Fm}^{\prime}$, stomatal conductance, LAI, SLA, and WUE. This cassava genotype, therefore, can be used as valuable genetic material for dry environments during the late growing stage. It is interesting that there was relationship between WUE and crop dry matter at dry circumstance of a final growth stage, and CMR38-125-77 and Kasetsart 50 were satisfactory genotype for both WUE and dry matter. Measurement of WUE along with biomass, therefore, could help provide better understanding on cassava growth habit and support a more accurate decision for genotypes classification under drought conditions during high storage root formation.

Author Contributions: Conceptualization, S.W., P.B., N.V., S.J., and P.T.; data curation, S.W.; formal analysis, S.W. and P.B.; methodology, S.W., P.B., N.V., S.J., and P.T.; supervision, P.B.; investigation, S.W. and P.B.; writing (original draft preparation), S.W. and P.B.; writing (review and editing), S.W., P.B., N.V., S.J., and P.T. All authors have read and agreed to the published version of the manuscript.

Funding: This study was supported by National Science and Technology Development Agency (NSTDA), Thailand. Assistance in conducting the work was also received from Agronomy Department and the Plant Breeding Research Center for Sustainable Agriculture, Khon Kaen University, Thailand.

Acknowledgments: Special thanks to Khon Kaen University for providing facilities in conducting this experiment, and we would like to thank the members of the cassava team project and technicians of the agronomy department for their help in field data collection and laboratory analyses.

Conflicts of Interest: The authors declare no conflict of interest.

\section{References}

1. El-Sharkawy, M.A. Cassava biology and physiology. Plant Mol. Biol. 2003, 53, 621-641. [CrossRef]

2. Howeler, R.; Lutaladio, N.; Thomas, G. Save and Grow: Cassava-A Guide to Sustainable Production Intensification; Food and Agriculture Organization: Rome, Italy, 2013.

3. Sriroth, K.; Piyachomkwan, K.; Wanlapatit, S.; Nivitchanyong, S. The promise of a technology revolution in cassava bioethanol: From Thai practice to the world practice. Fuel 2010, 89, 1333-1338. [CrossRef]

4. Anyanwu, C.N.; Ibeto, C.N.; Ezeoha, S.L.; Ogbuagu, N.J. Sustainability of cassava (Manihot esculenta Crantz) as industrial feedstock, energy and food crop in Nigeria. Renew. Energ. 2015, 81, 745-752. [CrossRef]

5. Bhuiyan, M.M.; Iji, P.A. Energy value of cassava products in broiler chicken diets with or without enzyme supplementation. Asian Austral. J. Anim. 2015, 28, 1317-1326. [CrossRef] [PubMed]

6. Tonukari, N.; Ezedom, T.; Enuma, C.C.; Sakpa, S.O.; Awioroko, O.J.; Eraga, L.; Odiyoma, E. White gold: Cassava as an industrial base. Am. J. Plant Sci. 2015, 6, 972-979. [CrossRef]

7. FAO. Statistics Databases: Production; FAO: Rome, Italy, 2017; Available online: http:/www.fao.org/faostat/en/ \#data/QC (accessed on 15 January 2019).

8. Connor, D.J.; Cock, J.H.; Parra, G.E. Response of cassava to water shortage. I. Growth and yield. Field Crop Res. 1981, 4, 181-200. [CrossRef]

9. El-Sharkawy, M.A. Physiological characteristics of cassava tolerance to prolonged drought in the tropics: Implications for breeding cultivars adapted to seasonally dry and semiarid environments. Braz. J. Plant Physiol. 2007, 19, 257-286. [CrossRef]

10. Kawano, K. Harvest index and evoluation of major food crop cultivars in the tropics. Euphytica 1990, 46, 195-202. [CrossRef]

11. De Tafur, S.M.; El-Sharkawy, M.A.; Calle, F. Photosynthesis and yield performance of cassava in seasonally dry and semiarid environments. Photosynthetica 1997, 33, 249-257. [CrossRef] 
12. Oyetunji, O.J.; Ekanayake, I.J.; Osonubi, O. Chlorophyll fluorescence analysis for assessing water deficit and arbuscular mycorrhizal fungi (AMF) inoculation in cassava (Manihot esculenta Crantz). Adv. Biol. Res. 2007, 1, 108-117.

13. Vandegeer, R.; Rebecca, E.; Bain, M.; Roslyn, M.; Timothy, R. Drought adversely affects tuber development and nutritional quality of the staple crop cassava (Manihot esculenta Crantz). Funct. Plant Biol. 2013, 40, 195-200. [CrossRef]

14. Sawatraksa, N.; Banterng, P.; Jogloy, S.; Vorasoot, N.; Hoogenboom, G. Chlorophyll fluorescence and biomass of four cassava genotypes grown under rain-fed upper paddy field conditions in the tropics. J. Agron. Crop Sci. 2018, 204, 554-565. [CrossRef]

15. Alves, A.A.C. Cassava Botany and Physiology. In Cassava: Biology, Production and Utilization; Hillocks, R.J., Thresh, J.M., Bellotti, A.C., Eds.; CABI Publishing: New York, NY, USA, 2002; pp. 67-89.

16. Shukla, A.; Panchal, H.; Mishra, M.; Patel, P.R.; Srivastava, H.S.; Patel, P.; Shukla, A.K. Soil moisture estimation using gravimetric technique and FDR probe technique: A comparative analysis. Am. Int. J. Res. Form. Appl. Nat. Sci. 2014, 8, 89-92.

17. Impa, S.M.; Nadaradjan, S.; Boominathan, P.; Shashidhar, G.; Bindumadhava, H.; Sheshshayee, M.S. Carbon isotope discrimination accurately reflects variability in WUE measured at a whole plant level in rice. Crop Sci. 2005, 45, 2517-2522. [CrossRef]

18. Murchie, E.H.; Lawson, T. Chlorophyll fluorescence analysis: A guide to good practice and understanding some new applications. J. Exp. Bot. 2013, 64, 3983-3998. [CrossRef] [PubMed]

19. Vongcharoen, K.; Santanoo, S.; Banterng, P.; Jogloy, S.; Vorasoot, N.; Theerakulpisut, P. Seasonal variation in photosynthesis performance of cassava at two different growth stages under irrigated and rain-fed conditions in a tropical savanna climate. Photosynthetica 2018, 56, 1398-1413. [CrossRef]

20. Vongcharoen, K.; Santanoo, S.; Banterng, P.; Jogloy, S.; Vorasoot, N.; Theerakulpisut, P. Diurnal and seasonal variations in the photosynthetic performance and chlorophyll fluorescence of cassava 'Rayong 9' under irrigated and rainfed conditions. Photosynthetica 2019, 57, 268-285. [CrossRef]

21. Santanoo, S.; Vongcharoen, K.; Banterng, P.; Vorasoot, N.; Jogloy, S.; Roytrakul, S.; Theerakulpisut, P. Seasonal variation in diurnal photosynthesis and chlorophyll fluorescence of four cultivars of cassava (Manihot esculenta Crantz.) under irrigation conditions in a tropical savanna climate. Agronomy 2019, 9, 206. [CrossRef]

22. Gonzalez, L.; Gonzalez-Vilar, M. Determination of Relative Water Content. In Handbook of Plant Ecophysiology Techniques; Roger, M.J.R., Ed.; Kluwer Academic Publishers: Dordrecht, The Netherlands, 2001; pp. 207-212. [CrossRef]

23. Wholey, D.W.; Booth, R.H. A comparison of simple methods for estimating starch content of cassava roots. J. Sci. Food Agric. 1979, 30, 158-164. [CrossRef]

24. Gomez, K.A.; Gomez, A.A. Statistical Procedures for Agricultural Research; John Wiley and Sons: New York, NY, USA, 1984.

25. Statistix, version 10; Analytical Software: Tallahassee, FL, USA, 2013.

26. Phoncharoen, P.; Banterng, P.; Vorasoot, N.; Jogloy, S.; Theerakulpisut, P.; Hoogenboom, G. Growth rates and yields of cassava at different planting dates in a tropical savanna climate. Sci. Agric. 2019, 76, 376-388. [CrossRef]

27. Sawatraksa, N.; Banterng, P.; Jogloy, S.; Vorasoot, N.; Hoogenboom, G. Cassava growth analysis of production during the off-season of paddy rice. Crop Sci. 2019, 59, 760-771. [CrossRef]

28. Cock, J.H.; Franklin, D.; Sandoval, G.; Juri, P. The ideal cassava plant for maximum yield. Crop Sci. 1979, 19, 271-279. [CrossRef]

29. El-Sharkawy, M.A.; Cadavid, L.F. Response of cassava to prolonged water stress imposed at different stages of growth. Exp. Agric. 2002, 38, 333-350. [CrossRef]

30. Phosaengsri, W.; Banterng, P.; Vorasoot, N.; Jogloy, S.; Theerakulpisut, P. Leaf performances of cassava genotypes in different seasons and its relationship with biomass. Turk. J. Field Crops 2019, 24, 54-64. [CrossRef]

31. El-Sharkawy, M.A.; Hernandez, A.D.P.; Hershey, C. Yield stability of cassava during prolonged mid-season water stress. Exp. Agric. 1992, 28, 165-174. [CrossRef]

32. El-Sharkawy, M.A. Drought-tolerant cassava for Africa, Asia, and Latin America: Breeding projects work to stabilize productivity without increasing pressures on limited natural resources. Bioscience 1993, 43, 441-451. [CrossRef] 
33. Turyagyenda, L.F.; Kizito, E.B.; Ferguson, M.; Baguma, Y.; Agaba, M.; Harvey, J.J.W.; Osiru, D.S.O. Physiological and molecular characterization of drought responses and identification of candidate tolerance genes in cassava. AoB Plants 2013, 5, plt007. [CrossRef]

34. El-Sharkawy, M.A. Prospects of photosynthetic research for increasing agricultural productivity, with emphasis on the tropical C4 Amaranthus and the cassava C3-C4 crops. Photosynthetica 2016, 54, 161-184. [CrossRef]

35. De Souza, A.P.; Long, S.P. Toward improving photosynthesis in cassava: Characterizing photosynthetic limitations in four current African cultivars. Food Energy Secur. 2018, 7, e00130. [CrossRef]

36. Sinclair, T.R.; Muchow, R.C. System analysis of plant traits to increase grain yield on limited water supplies. Agron. J. 2001, 93, 263-270. [CrossRef]

37. Shan, Z.; Luo, X.; Wei, M.; Huang, T.; Khan, A.; Zhu, Y. Physiological and proteomic analysis on long-term drought resistance of cassava (Manihot esculenta Crantz). Sci. Rep. 2018, 8, 17982. [CrossRef] [PubMed]

38. Lawlor, D.W. Limitation to photosynthesis in water-stressed leaves: Stomata vs. metabolism and the role of ATP. Ann. Bot. 2002, 89, 871-885. [CrossRef] [PubMed]

39. Lawlor, D.W.; Cornic, G. Photosynthetic carbon assimilation and associated metabolism in relation to water deficits in higher plants. Plant Cell Environ. 2002, 25, 275-294. [CrossRef] [PubMed]

40. Phoncharoen, P.; Banterng, P.; Vorasoot, N.; Jogloy, S.; Theerakulpisut, P.; Hoogenboom, G. The impact of seasonal environments in a tropical savanna climate on forking, leaf area index, and biomass of cassava genotypes. Agronomy 2019, 9, 19. [CrossRef]

(C) 2020 by the authors. Licensee MDPI, Basel, Switzerland. This article is an open access article distributed under the terms and conditions of the Creative Commons Attribution (CC BY) license (http://creativecommons.org/licenses/by/4.0/). 